\title{
Self-protection: how NHS doctors are sourcing their own PPE
}

As central supplies of personal protective equipment fail to match the demand created by the covid-19 pandemic, UK medics are taking matters into their own hands. Fran Robinson reports

\section{Fran Robinson}

London

Back in early March, before the covid-19 pandemic had taken hold in the UK and before PPE (personal protective equipment) had become a household term, Sadaf Farooqi and Toni Vidal-Puig were already planning how to source stocks from China.

"We were in contact with friends and colleagues treating patients in other countries and were hearing that PPE was an issue. Although at that time stocks were adequate in the UK, clinicians were becoming nervous about the future availability of PPE," says Farooqi-like Vidal-Puig, a professor from the Wellcome-MRC Institute of Metabolic Science in Cambridge and a specialist in obesity and metabolic disease research.

Farooqi and Vidal-Puig's efforts are just one example of resourceful doctors around the UK increasingly taking the supply of PPE into their own hands, to deal with the twin scandals of NHS equipment shortages and healthcare workers dying with covid-19.

Half of doctors working in high risk areas reported shortages or no supply of long sleeved disposable gowns, goggles, and visors in a BMA survey of 6000 respondents in mid-April. Almost two thirds of GPs reported shortages of eye protection or none at all. ${ }^{1}$

\section{Cambridge-China collaboration}

Leading a team of clinicians, biomedical scientists, and engineers, Farooqi and Vidal-Puig launched an appeal—4CPPE (www.4CPPE.com), backed by the University of Cambridge_-aiming to raise $£ 5 \mathrm{~m}(€ 5.7 \mathrm{~m} ; £ 6.2 \mathrm{~m})$, and they are working with academic colleagues in China to source high grade items for the East of England region.

Vidal-Puig has an academic collaboration with Daping Chu at the Cambridge University-Nanjing Centre for Technology and Innovation in China, whose team offered to help by identifying reliable suppliers of PPE. They have already sent donations of 4000 gowns and 20000 surgical masks to Cambridge. Chinese entrepreneurs, some of whom trained at Cambridge, are helping to arrange air freight.

Vidal-Puig explains, "We are in contact with local academics and their teams who know what is happening on the ground in China. This is a perfect example of academic collaboration across two countries and of the trust that you build up over time, which is incredibly helpful at a time of crisis."

\section{Community spirit}

Concerned that his practice had very little PPE and almost no eye protection, Greg Irving, a St Helens general practitioner and academic at the University of Cambridge, put out a call for help through his local community's coronavirus support group. He uploaded a 3D print manufacturer's verified design for a face shield and asked whether anyone could make them on a 3D printer.

Within six hours he had the first one on his desk. Volunteers set up a crowdfunding appeal and very quickly raised $£ 3000$. Several other local organisations soon came on board, including the Steve Prescott Foundation, a local charity that's helping to obtain the materials needed for the face shields. The comedian Johnny Vegas, who works with the charity, has been raising awareness of the initiative and helping with deliveries.

The group has so far produced about 3500 face shields. Half have been supplied to the local covid-19 primary care "hot hub," and the rest have been sent to other GP surgeries, acute trusts, the local hospice, district nurses, and care homes. The group is now making plastic door openers to protect people's hands from infection.

Irving says, "We have had individuals, schools, local colleges, and the Chamber of Commerce all working on this-everything we have asked for has been done for us." 


\section{Offers of help reach 8000}

A few weeks ago a similar small initiative to supply face shields to local organisations was launched by James Moxon, a palliative care doctor from Pembury with an interest in technology, and it has spiralled into an organisation with a million orders.

3D Crowd UK (https://www.3dcrowd.uk/) began as a post on a website. This led to a crowdfunding campaign that has attracted 8000 offers of help from both hobbyist and professional $3 \mathrm{D}$ printers.

Moxon has since withdrawn from the initiative, to focus on his clinical work. A spokeswoman said that the campaign group was constantly hearing how urgently frontline staff needed this equipment. She said, "The desperation is palpable when we speak to them on the phone. More than once we've had tearful senior physicians pleading with us for anything we can send."

\section{Repurposed and reusable snorkel masks}

A group of six plastic surgeons at the Oxford University Hospitals Trust have also formed a campaign, Oxford InSpired (https://www.crowdfunder.co.uk/new-development-of-reusableppe-for-nhs-staff), to raise funds to develop a new face mask that they say provides safer and more effective protection than standard equipment.

The mask, adapted from commercially available snorkel masks, can be cleaned and reused. A prototype mask has been created and is currently being tested and certified. Once this process is complete, Oxford InSpired will start mass producing and distributing the masks. Each mask costs $£ 50$ to produce, and the group aims to raise $£ 150000$ to make 3000 masks.

One of the plastic surgery registrars is Ryan Kerstein, who says that their trust currently has adequate PPE supplies but that they are concerned about colleagues around the country who may not be as fortunate. He says, "Although supplies are being distributed, the speed at which they are being consumed and the length of time we are likely to be treating patients with covid-19 will likely cause ongoing shortage and supply problems for the foreseeable future.

"Looking ahead, we are likely to be using level 2 PPE for many months if not years to come. Therefore, even in areas where supply is currently adequate, this supply may not be sustainable." (Level 2 PPE requires the user to wear a respirator mask and eye protection when performing aerosol generating procedures.)

\section{Celebrity donations}

A neurosurgeon, a physician, a GP, and the businessman Nav Kumar have launched a crowdfunding appeal to raise $£ 200000$ to buy PPE from China—and have collected over $£ 2 \mathrm{~m}$ in just a few weeks. Their appeal, Masks for NHS Heroes (https://www. crowdfunder.co.uk/masks4nhsheroes), gained a huge boost when the actor James McAvoy and other celebrities donated substantial sums of money and helped to publicise the campaign to their followers.

The appeal was launched only two weeks before the UK lockdown began but has already supplied 100000 face shields, 100000 visors, 70000 gowns and masks, and 200000 respirators to 30 acute hospital trusts in the UK. A second delivery supplied a further 16 acute trusts, four clinical commissioning groups, a care home, a hospice, and a regional ambulance service.
Thirty volunteers with public relations and legal expertise are helping behind the scenes, and the courier DHL has helped to fly in and distribute the supplies. The group now aims to raise $£ 3 \mathrm{~m}$, and for its next delivery it's looking to secure 500000 isolation gowns and a million face masks.

One of the doctors in the group, Ravi Visagan, a neurosurgery registrar at King's College Hospital in London, says, "Healthcare workers on the front line without PPE is the equivalent of going to war without armour and protection."

\section{Royal scrubs and chef's trousers}

Penelope Law, obstetrician at Hillingdon Hospital and the Countess of Bradford, has been using her personal contacts to source PPE for her staff: she has persuaded the royal couturier Stewart Parvin to make scrubs, and Dennys Brands, a supplier of hospitality clothing and uniforms, will supply 1000 pairs of chef's trousers.

When her hospital ran out of towels for staff, Law reached out to a sales director at Primark, who sent a truck branded with "We love the NHS" and filled with huge packs of towels, each packed with "thank you" notes from volunteers.

Her brother Fraser is using his design company, IDology, to make a plastic device for pushing staff badges against door scanners. And when, during a shopping trip to Marks \& Spencer, Law noticed the staff wearing visors, she made inquiries and contacted a Loughborough based company called SDI, which sent her 100 visors free of charge.

She agreed to be interviewed by the Daily Mail after the newspaper's proprietor, Jonathan Harmsworth (Lord Rothermere), promised to send a plane to China to obtain $£ 1 \mathrm{~m}$ worth of equipment. She has sent him her shopping list, which includes ventilators and continuous positive airway pressure (CPAP) machines.

Law says that she's not surprised at the efforts doctors are making to source their own equipment. She explains: "Clinicians know what is important, and they are much more used to making fast decisions. We are aware that anybody could get ill. I'm just trying to make sure that everybody's protected."

\section{The gaps in NHS stocks of PPE}

The BMA is running snapshot surveys of doctors' access to PPE. In the latest survey, conducted with more than 6000 respondents in mid-April, just under a third of doctors said that they were sometimes pressured to work without adequate protection. Almost one in five doctors did not feel safely protected at work. ${ }^{1}$

One doctor said that the levels of PPE were like being "thrown to the wolves." The Doctors' Association UK and Messly, a team of doctors and tech experts, have collaborated to create the NHSppe.com app, which collects real time data about stock levels of PPE from the NHS front line. ${ }^{2}$

Data collected up to 27 April from 1095 respondents from 257 hospitals and general practices showed that:

$38 \%$ of respondents reported having no eye protection

$23 \%$ of respondents performing aerosol generating procedures (AGPs) had no eye protection

$38 \%$ of respondents performing AGPs had no FFP3 masks or hoods (the highest level of protection)

$47 \%$ of respondents performing AGPs did not have long sleeved gowns, and

. $60 \%$ of respondents had not been fit tested for FFP3 masks.

Respondents' comments included:

"Elective caesarean sections were cancelled today due to the non-availability of long sleeve surgical gowns."

"There is collection and laundering of single use water resistant surgical gowns."

"We are reusing gowns and visors now. FFP3 masks are in short supply. Surgical masks [are] now running low and being rationed." 
Competing interests: I have read and understood BMJ policy on declaration of interests and have no relevant interests to declare.

Provenance and peer review: Commissioned; not externally peer reviewed.
1 Blackburn P. Half of doctors source own PPE. BMA. 4 May 2020. https://www.bma.org. uk/news-and-opinion/half-of-doctors-source-own-ppe.

2 Messly, Doctors' Association UK. NHSppe app. https://www.nhsppe.com.

Published by the BMJ Publishing Group Limited. For permission to use (where not already granted under a licence) please go to http://group.bmj.com/group/rights-licensing/ permissions 